\title{
BROILER PERFORMANCE, ENZYMES ACTIVITY AND HISTOLOGICAL OBSERVATIONS AFFECTED BY MULTI ENZYMES COMPLEX (ZADO®)
}

\author{
M.H.S. El-Sanhoury and A.M.H. Ahmed \\ Poultry Production Department, Faculty of Agriculture, Ain Shams University, Cairo, Egypt
}

(Received 25/5/2017, Accepted 10/7/2017)

\section{SUMMARY}

\begin{abstract}
$\mathrm{T}$ he aim of this study was to evaluate multi enzymes complex (ZADO®) on broiler performance, enzymes activity, some blood parameters and histological observations. 225 one- day unsexed Hubbard chicks were distributed into 5 equal group (45 chicks). Each experimental group was divided into five replicates ( 9 chicks/each). The first group was served as control and fed basal diets. While, the other groups received the basal diet supplemented with $0.1,0.3,0.5$ and $0.7 \mathrm{~kg}$ ZADO® on ton diets, $\mathrm{z} 1$, $\mathrm{z} 2, \mathrm{z} 3$ and $\mathrm{z} 4$, respectively. This product contains a mix of anaerobic bacteria and their enzymes of xylanases ( 2.3 unit/g), cellulases $(7.1$ unit/g), alpha-amylase $(61.5 \mathrm{unit} / \mathrm{g})$ and protease $(29.2 \mathrm{unit} / \mathrm{g})$. Our obtained results indicated that the use of this multi-enzyme at $0.5 \mathrm{Kg} /$ tonaffect positively in the $\mathrm{BW}$ of broilers. The enhancement in both stomach and intestine enzymes activities in all supplemented groups with ZADO®are good explanations for the improvements in the FCR. The histological observations for liver and intestine and blood pictures showed that non-significantly differences among groups with or without supplementations. These findings may indicate that this product seems to be safe on birds and accordingly birds are safe for human consumption. Good of Economic Efficiency for ZADO® $0.5 \mathrm{Kg} / \mathrm{ton}$.
\end{abstract}

Keywords: $Z A D O ®$, broiler performance, enzyme activity, blood components.

\section{INTRODUCTION}

It is well known that exogenous enzymes have been used to enhance the feeding values of feed stuffs are high in soluble non- starch polysaccharides that induce viscosity (Mathlouthiet al., 2002; Lazaro et al., 2003). However, it has been reported also that enzyme cocktail (carbohydrase and protease) improve the productivity (saleh et al., 2005) and digestibility of corn and soybean meal, which induce less viscosity for broilers (Zanella et al., 1999; Graacia et al.,2003; Olukosi et al., 2007; Cowieson and Ravindran, 2008).

The addition of exogenous enzymes to broiler chicken feeds has gained increasing attention because of both environmental and economic aspects. Their prospect is to stimulate a better utilization of the diet, because less feed is needed to produce a certain amount of meat and fewer nutrients end up in the litter (Kalmendal and Tauson, 2012). Branded enzyme products can be categorized into single (monocomponent) enzymes blends of mono-component enzymes and fermentation products from wild type microorganism strains expressing a spectrum of enzyme activities (Freitas et al., 2011).

The efficacy of many commercial enzyme products has been well stated, but there is still some vagueness in their mode of action (Bedford, 2002). Moreover, several reports indicated that dietary enzymes improve the digestibility of nutrients in broilers (Graciaet al., 2003; Cowieson and Ravindran, 2008; Kalmendal and Tauson, 2012). In addition, Gao et al. (2007) suggested that enzyme supplementation accelerated the development of the immune organs. In this respect, the author hypothesized that the improvement of the nutrient digestibility might be reflected in enhancing immunity and modifies blood metabolites profile especially, if these enzymes are prepared at ensiling from anaerobic bacterium (Safaa et al., 2010). Also, for this reason liver and kidney might be work better in response to dietary enzymes and their functions might be improved.

An Egyptian patented product (ZADO®), which is a commercial exogenous enzyme mixture prepared from anaerobic bacterium, has been shown to improve ruminal fermentation, $\mathrm{N}$ balance and nutrient digestibility, as well as milk yield of cows fed diets containing Egyptian by-product feeds (Gado et al.,2007; Gado et al., 2009), as well as live body weight (BW) gain (BWG) and feed conversion ratio 


\section{El-Sanhoury and Ahmed}

(FCR) of sheep and goats fed diets contained wheat straw (Gado, 1997; Gado and Salem, 2008; Gado et al.,2011). In addition, dietary serine protease derived from fermentation of Bacillus lichenifomis in cornSBM-based broiler diets resulted in improved BW, feed efficiency and digestibility of fat, protein (Freitas et al.,2011) and amino acids (Angel et al., 2011). Therefore, the aim of this study was to evaluate the impacts of ZADO ${ }^{\circledR}$ supplementation to broiler diets on productive performance slaughter traits and blood metabolites in chicken broilers.

\section{MATERIALS AND METHODS}

A total number of 225 one d-old Hubbard broiler chicks were used in this study. The broiler chicks were nearly equal in the live body weight and divided randomly into five treatment groups of 45 chicks each. Each experimental group was divided into five replicates ( 9 chicks/each). The first group was served as control and fed basal diets. While, the other groups received the basal diet supplemented with $0.1,0.3,0.5$ and $0.7 \mathrm{~kg}$ ZADO ${ }^{\circledR}$ on ton diets, $\mathrm{z} 1, \mathrm{z} 2, \mathrm{z} 3$ and $\mathrm{z} 4$ respectively. ZADO® is a patented product manufactured by the Academy of Scientific Research and Technology, Egypt and contains a mix of anaerobic bacteria and their enzymes of xylanases $(2.3 \mathrm{unit} / \mathrm{g})$, cellulases $(7.1 \mathrm{unit} / \mathrm{g})$, alpha-amylase (61.5 unit/g) and protease (29.2 unit/g) in a powder form obtained through an anaerobic fermentation process (Gado et al., 2009; Gado et al., 2011). This study was terminated when the birds were 35 days old. All chicks were vaccinated against Newcastle disease, at seven and twenty two days of age with Hitchener B1 and Lasota strain vaccine, respectively and Gumboro vaccine against Bursal disease at fourteen days of age.

The experimental period included two feeding phases (starter, from 1-21 days of age and finisher, from 21-35days of age). Experimental diets were formulated to nearly meet the nutrient requirements of the broiler chicks (NRC, 1994). The composition and chemical analysis of the control basal diets are presented in Table (1). The chemical composition of the experimental diets was analyzed according to A.O.A.C. (2000).

Table (1): Composition, calculated and chemical analysis of the basal diets

\begin{tabular}{lll}
\hline Ingredients (\%) & Starter (0-3 Weeks) & Finisher (3-5 Weeks) \\
\hline Yellow corn & 57.77 & 71.00 \\
Soybean meal (44\%CP) & 25.5 & 13.60 \\
Corn gluten meal & 10.00 & 10.00 \\
Vegetable oil & 3.00 & 2.00 \\
Bone meal & 2.60 & 2.00 \\
Limestone & 0.30 & 0.60 \\
Vit\& Min Premix* & 0.30 & 0.30 \\
NaCl & 0.25 & 0.25 \\
L-Lysine & 0.18 & 0.20 \\
DL-Methionine & 0.10 & 0.05 \\
Total & 100 & 100 \\
A-Chemical analysis:- & & \\
Crude protein \% & 22.16 & 18.00 \\
Crude fiber \% & 3.53 & 3.13 \\
Ether extract \% & 2.86 & 3.12 \\
Ash \% & 6.77 & 6.58 \\
B-Calculated analysis: & 3139 & 3221 \\
ME (Kcal/Kg diet) & 1.02 & 0.90 \\
Calcium \% & 0.45 & 0.35 \\
Available phosphorous \% & 1.15 & 0.90 \\
Lysine \% & 0.51 & 0.40 \\
Methionine \% & 0.38 & 0.33 \\
Cystine \% & 0.89 & 0.73 \\
Meth. + Cys. \% & &
\end{tabular}


Feed and water were supplied ad-libitium during the experimental periods and birds were exposed to 24 hours of constant light. All chicks were kept under the same managerial, hygienic and environmental conditions. Chicks were individually weight at the beginning of the experiment, then at weekly intervals until the end of experiment, live body weight (LBW), body weight gain (BWG), feed consumption (FC), feed conversion ratio (FCR, $\mathrm{g}$ feed/g gain) were recorded during these periods.

At the age of $35 \mathrm{~d}$, ten birds ( 5 males and 5 females) from each experimental group were weighed and slaughtered by slitting the jugular vein, then scalded and defeathered. Carcasses were manually eviscerated and weighted. Liver, heart, gizzard, spleen, thymus (all lobes of both sides), bursa, small intestine and abdominal fat were removed and their relative percentages of live body weight were estimated. The intestinal length $(\mathrm{cm})$ was also considered and the intestinal density ( $\mathrm{g}$ weight/ length, $\mathrm{cm}$ ) was calculated. The same located segments of their digestive tract (stomach and intestine) were emptied by gentle squeezing, contents of individual segments were taken and mixed and about $1 \mathrm{~g}$ of the mixed content was immediately diluted with $10 \mathrm{ml}$ of distilled water. All samples were centrifuged for 10 minutes. The supernatant fluid was taken and stored in sealed bottles at $-20^{\circ} \mathrm{C}$ until analyzed. Enzymes activity in digestive content of stomach, and intestine of chicks were determined as follows: amylase (Osman, 1982), protease (Malik and Singh, 1982), cellulase (Halliwell, 1958) and carboxymethylcellulase (Mandels and Waber, 1969).

Blood samples were collected from the ten slaughtered birds in nonheparinized tubes. The blood samples were centrifuged at $3000 \mathrm{rpm}$ for $15 \mathrm{~min}$. and serum obtained was stored at $-20 \mathrm{C}$ until analysis. Serum total protein, albumin, triglycerides, total cholesterol, creatinine, Aspartate aminotransferase (AST), Alanine aminotransferase (ALT) and minerals (calcium and phosphorous) were determined calorimetrically by using available commercial kits purchased from Diamond Diagnostics Company. The globulin values were calculated by subtracting the values of albumin from the corresponding values of total protein. Serum concentration of triiodothyronine (T3) and thyroxine (T4) were determined using commercial enzyme immunoassay test kit purchased from Taytec Incorporation (7278 Aldercreast Dr., Mississauga, ON, L5N7N8, Canada).

The economic efficiency was calculated according to the price of local market at the time of carrying out the experiment as follows: Economic efficiency $=(\mathrm{A}-\mathrm{B} / \mathrm{B}) \times 100$.

Where: $\mathrm{A}=$ Price of $\mathrm{kg}$ gain in Egyptian pounds $\mathrm{B}=$ Feed cost $/ \mathrm{kg}$ gain in Egyptian pounds.

Performance index (PI) was calculated according to North (1981) as follows:

$$
\mathrm{PI}=\text { [live body weight }(\mathrm{kg}) / \text { feed conversion ratio }] \times 100 \text {. }
$$

The production efficiency factor (PEF) was calculated according to Emmert (2000) as follows:

$\mathrm{PEF}=[$ Livability $\times$ Mass $(\mathrm{Kg}) / \mathrm{FCR} \times$ Age in days $] \times 100$

Where: Livability $=100-$ Mortality rate $(\%)$

Mass $(\mathrm{Kg})=$ Final live body weight.

Data were statistically analyzed by using the General Linear models (GLM) procedures of SAS (SAS, 2004). The model was as follows: $\mathrm{Yij}=\mu+\mathrm{Ti}+\mathrm{eij}$

Where: $\mathrm{Yij}=$ The observation on the Ith treatment $\mu=$ Overall mean, $\mathrm{Ti}=$ Effect of the Ith treatment, eij $=$ Random error treatment. Significant differences among treatment means were determined by Duncan's multiple range test (Duncan, 1955).

\section{RESULTS AND DISCUSSION}

\section{Performace traits:}

The effects of dietary treatments on BW, FCR, and mortality are shown in Table (2). The level of $0.5 \mathrm{Kg} \mathrm{ZADO}{ }^{\circledR}$ supplementation in the diets of broiler affect positively in the $\mathrm{BW}$ and the livability of the broilers at the growing period than this fed control diets.

The results showed significantly $(\mathrm{P} \leq 0.05)$ higher body weight at 21 day of age for the group supplemented with Z3 than other groups and the same trend was recorded at 35 day of age. The best LBW $(\mathrm{P} \leq 0.01)$ was recorded for Z3 group than control, Z2 and Z4 groups. Concerning daily weight gain, the groups supplemented with Z3 \& Z4 and Z2 showed higher daily weight gain than control group 


\section{El-Sanhoury and Ahmed}

(Table 2). The highest values were recorded for Z3 group followed by Z4 \& Z2 groups which were equally similar at $7-21,21-35$ and at $7-35$ day of age. The good FCR for chicken feed diet supplemented with Z3followed by Z4 and Z2 which were equally similar at 7-21, $21-35$ and at $7-35$ day of age. These results are in agreement with several reports regarding enzyme addition in broiler cornSBM-based diets. Kocher et al. (2003) reported that using an enzyme cocktail containing pectinase, amylase and protease in corn-SBM-based diets for chicks resulted in improved performance. Also, Cowieson et al. (2006) indicated that exogenous xylanase, amylase, protease and phytase (Avizyme) can be used successfully in a strategically formulated low nutrient density diet to maintain performance to that of birds fed on a nutritionally adequate diet. In addition, Cowieson and Ravindran (2008) stated that supplementing corn-SBM-based broiler diets with an enzyme product containing xylanase, amylase and protease improved BWG and feed efficiency compared with the un-supplemented diets, but feed intake did not affected. They also, reported that the energy and amino acid values of corn-SBM-based diets for broiler can be enhanced by supplementation with an enzyme cocktail of xylanase, amylase and protease, offering potential economic benefits to producers. The mode of action of enzymes in corn-SBM-based diets has been linked to improved starch digestibility associated with augmentation of endogenous alphaamylase or improved digestion of resistant starches, improved access to cell contents via a reduction in cell wall integrity, modification of the intestinal microbial communities, improved protein solubility and digestibility and a reduction in the inimical effects of maize and/or soy-derived anti-nutrient factors. In the same context, Saleh et al, (2005) reported that the commercial enzymes, which are mostly comprised of carbohydrases and contain small amount of protease activity (Energex) improved significantly the productivity (BWG and FCR) of broilers fed corn-SBM-based diets in compare to pure carbohydrases (cellulose, hemicellulose and pectinase) supplementation, which tended to affect in compare to control group (without enzyme supplementation). However, they noted that feed intakes were not affected by dietaty enzymes. Similar results have been found earlier by Zanellaet al. (1999) when they supplemented a corn-SBM diet with Avizyme, a commercial enzyme; BWG and FCR were significantly improved by Avizyme. They demonstrated that the energy and amino acid digestibility of a corn-SBM-based diet for broiler could be improved by around 3\% when supplemented with xylanase, amylase and protease allowing performance to be maintained on a diet with a lower nutritional plane. In addition, Kalmendal and Tauson (2012) observed that the combination of xylanase and serine protease improved FCR, compared with the control diet but, BW and FI were not affected by enzyme addition sole or mixed. Moreover, Graciaet al, (2003) demonstrated that amylase was a critical enzyme to improve the nutritional value of corn-based broiler diets, improved BWG and FCR by 4 to $9 \%$ compared with an unsupplemented control diet. Remus et al. (2005) summarized the effect of a combination of xylanase, amylase and protease on ileal digestibility of amino acids for 5 broiler trials and found a mean response of around $2 \%$. However, though highly significant, these effects were amino acid dependent, for example, for threonine $(>2 \%)$ vs. methionine $(<0.5 \%)$ and the reasons for the differential responses are not clear.

Table (2): Effect of feeding different levels of ZADO® on productive performance of growing chicks.

\begin{tabular}{|c|c|c|c|c|c|c|}
\hline Item & Control & $\mathrm{Z} 1$ & $\mathrm{Z2}$ & $\mathrm{Z3}$ & $\mathrm{Z4}$ & Prob. \\
\hline \multicolumn{7}{|c|}{ Live body weight (g) at: } \\
\hline At 7 days & $122.0+4.49$ & $127.0 \pm 5.11$ & $126.0 \pm 4.12$ & $124.05+3.99$ & $125.0+5.12$ & 0.74 \\
\hline 21days & $658.3 \overline{7}^{\mathrm{c}} \pm 10.13$ & $690.3 \overline{5}^{\mathrm{b}}+11.25$ & $702.39^{\mathrm{b}}+13.22$ & $765.58^{\bar{a}} \pm 15.16$ & $712.39^{\mathrm{b}}+12.92$ & 0.032 \\
\hline 35days & $1614.96^{\mathrm{c}} \pm 15.3$ & $1717.52^{\bar{b}}+25.2$ & $1823.44^{\overline{a b}} \pm 20.2$ & $1925.72^{\bar{a}} \pm 30.3$ & $1843.44^{\overline{\mathrm{ab}}} \pm 22.2$ & 0.006 \\
\hline \multicolumn{7}{|c|}{ Daily body weight gain $(\bar{g})$ from: } \\
\hline $7-21$ days & $38.21^{\mathrm{c}} \pm 1.09$ & $40.21^{\mathrm{b}}+0.75$ & $41.19^{\mathrm{b}} \pm 0.89$ & $45.85^{\mathrm{a}} \pm 0.95$ & $41.95^{\mathrm{b}} \pm 0.99$ & 0.04 \\
\hline 21-35days & $68.62^{c} \pm 1.99$ & $73.75^{\mathrm{b}} \pm 2.02$ & $79.87^{\mathrm{b}} \pm 2.99$ & $82.81^{\mathrm{a}} \pm 3.01$ & $80.07^{\mathrm{b}} \pm 2.79$ & 0.01 \\
\hline 7-35 days & $53.09^{c} \pm 1.15$ & $56.77^{\mathrm{b}} \pm 1.39$ & $60.21^{\mathrm{ab}} \pm 1.29$ & $64.27^{\mathrm{a}} \pm 2.58$ & $61.08^{\mathrm{ab}} \pm 1.39$ & 0.01 \\
\hline \multicolumn{7}{|c|}{ Daily feed consumption (g) from: } \\
\hline $7-21$ days & $58.92 \pm 2.53$ & $59.83 \pm 3.46$ & $59.93 \pm 2.78$ & $61.93 \pm 2.98$ & $59.93 \pm 2.68$ & 0.58 \\
\hline 21-35days & $125.79 \underline{9}+4.58$ & $126.5 \pm 4.82$ & $130.79 \underline{9}+3.93$ & $133.0 \overline{7}+4.15$ & $130.79 \underline{9}+3.83$ & 0.63 \\
\hline 7-35 days & $92.36 \pm \overline{6} .23$ & $93.21 \pm 5.16$ & $95.36 \pm \overline{6} .16$ & $97.5 \pm 7.12$ & $95.36 \pm 5.96$ & 0.63 \\
\hline \multicolumn{7}{|c|}{ Feed conversion ratio (Feed/Gain) from: } \\
\hline $7-21$ days & $1.54^{\mathrm{a}} \pm 0.01$ & $1.49^{\mathrm{b}} \pm 0.03$ & $1.45^{\mathrm{b}} \pm 0.04$ & $1.35^{\mathrm{c}} \pm 0.03$ & $1.42^{\mathrm{b}} \pm 0.04$ & 0.002 \\
\hline 21-35days & $1.84^{\mathrm{a}} \pm 0.05$ & $1.72^{\mathrm{b}} \pm 0.06$ & $1.64^{\mathrm{b}} \pm 0.02$ & $1.61^{\mathrm{c}} \pm 0.01$ & $1.63^{\mathrm{b}} \pm 0.01$ & 0.020 \\
\hline 7-35 days & $1.74^{\mathrm{a}} \pm 0.02$ & $1.64^{\mathrm{b}} \pm 0.05$ & $1.58^{\mathrm{b}} \pm 0.05$ & $1.52^{c} \pm 0.02$ & $1.56^{\mathrm{b}} \pm 0.01$ & 0.008 \\
\hline Mortality \% & 5 & 4 & 3 & 2 & 3 & - \\
\hline
\end{tabular}

${ }^{a, b}$ Means within the same row with different superscripts are significantly different. 
Frigard et al. (1994) reported also, a significant improvement in live BW and feed efficiency in broilers at 14 and $20 \mathrm{~d}$ of age fed rye-corn-SBM based diet supplemented with commercial enzyme (2 $\mathrm{g} / \mathrm{Kg}$ diet; GP-5000, based on beta-glucanases and xylanases) than those of birds fed the corresponding un-supplemented diet. However, they noted an increase $(\mathrm{p}=0.001)$ in the cumulative feed intake, at the same ages, in response to dietary enzyme. Moreover, Onilude and Oso (1999a) reported that the supplementation of three enzyme mixture (amylase from macrophominaphaseolina, cellulase from fermentation of cassava root fiber by a Trichoderma sp.and pectinase from banana peel fermentation by Fusariumtricitum to broiler fiber-containing diets (containing $20.24 \%$ rice bran and $37.00 \%$ wheat bran) from 1 to $42 \mathrm{~d}$ of age improved live BW, BWG and FCR at $42 \mathrm{~d}$ of age. In addition, Sarica et al. (2005) reported that xylanase supplementation in broiler diets based on wheat-corn-SBM up to $42 \mathrm{~d}$ did not affected BWG (2244.2 vs. $2237.7 \mathrm{~g}$ ), feed intake (4005.8 vs. $3951.2 \mathrm{~g}$ ) or FCR (1.79 vs. $1.77 \mathrm{~g}: \mathrm{g}$ ) for control and treated birds, respectively. In the same trend, Cowiesonet al. (2013) have done 2 experiments with the same diets but, lower stocking density and different batches of maize and SBM were used in experiment 2. For birds fed adequate nutrients diets, in the first experiment, they noted an increase in feed intake (3767.4 g/42 d) in response to Avizyme (exogenous xylanase, amylase, protease and phytase) supplementation comparing to un-supplemented group. However, in the second experiment they reported a reduction in feed intake in response to dietary Avizyme vs. un-supplemented group. They attributed that to the lower stocking density in experiment 2 and to the increase of the ambient temperature during the first 2 weeks of experiment 1.

On the other hand, Marsman et al. (1997) showed no improvement in FCR or BWG when mixedenzyme preparation (carbohydrases and proteases) was added to the broiler diets from 7 to $25 \mathrm{~d}$ of age. Moreover, Kocher et al. (2002) reported that the addition of the enzymes complex containing glucanase, hemicellulose and pectinase from 4 to $38 \mathrm{~d}$ of age had no effect on BWG or FCR of male Cobb broilers fed on a corn-SBM diet. Also, Meng et al. (2006) stated that $0.05 \%$ enzyme (contained cellulase, pectinase, mannanase, xylanase and glucanase as main activities) supplementation to broiler diets based on corn-SBM and containing 15\% canola seed (20\% CP) improved FCR (from 1.412 to 1.370) from 5 to $18 \mathrm{~d}$ of age. However, no effects were observed by enzyme supplementation for feed intakes of 702.3 vs. $692.8 \mathrm{~g} / \mathrm{bird}$ and BWG of 497.0 vs. $505.9 \mathrm{~g} / \mathrm{bird}$ for control vs. supplemented enzyme group, respectively. In addition, Walk et al. (2011) used mono-component xylanase and protease products derived from other microorganisms, for 18 days post hatch, but found no positive effects on production performance in broiler chickens fed a corn-SBM-based diet. Also, Barekatainet al. (2013) observed that an admixture of xylanase and protease to broiler corn-SBM based diets up to $21 \mathrm{~d}$ of ages did not result in further improvement in productive performance represented by BWG, feed intake and FCR. If the enzymes were additive in their effect, it would be expected that the sum of the effect attributed to each enzyme individually should not be different from the effect attributed to the use of the enzymes in combination (Olukosi et al., 2007). From this point of view, the author suggesting that the accumulation of the additive effect of the enzymes and the effect of continuous enzyme supplementation from hatch to marketing (42 $\mathrm{d}$ of age) in the current trial might explain the differences between the above mentioned findings and the results of broiler productivity in the current trial.

\section{Digestive enzymatic activity:}

Digestive enzymes activities (amylase, protease, cellulase and xylanase) in different segments of gastrointestinal tract are presented in Table (3). As a result of stomach $\mathrm{pH}$, among groups, low amylase activity but significant differences in samples taken from stomach. Although, high amylase activity was recorded in the small intestin contents. The activity of amylase enzyme was increased more than 5 folds in Z3 and Z4 compared with either Z2 \& Z1 or control group. On the other hand, protease activity was significantly different among groups when estimated in stomach and in small intestin. In stomach, protease activity was more than 4 folds in $\mathrm{Z} 3$ and 2 folds comparing with $\mathrm{Z} 1$ and control groups. Whereas, the same trend was found for its activity in small intestin. These data may explain our results for the superiorety of supplemented broilers with ZADO® in live body weights and blood profile. These findings may reflect a good feed utilization, absorption and metabolism for birds when diets supplemented with ZADO®.

\section{Blood parameters:}

Data presented in Table (4) clarify the effect of feeding broilers on diets with different levels of ZADO® on plasma protein profile. Significant increases have been recorded in total protein and globulin in Z3 \& Z4 groups followed by Z2 and Z1. No significant differences in albumin were observed compared with control group. These findings in turn have influenced the A/G ratio as it declined from 
0.523 in the control to the range of 0.220 to 0.294 in the other treatments. The reduction in $\mathrm{A} / \mathrm{G}$ ratio may reflect an enhancement of broilers immunity.

Table (3): Effect of different levels of ZADO® on enzymes activity of broiler

\begin{tabular}{|c|c|c|c|c|c|c|}
\hline Item & Control & $\mathrm{Z} 1$ & $\mathrm{Z} 2$ & $\mathrm{Z3}$ & $\mathrm{Z4}$ & Prob. \\
\hline \multicolumn{7}{|c|}{ In stomach content:- } \\
\hline Amylase & $0.35^{\mathrm{c}} \pm 0.199$ & $0.75^{\mathrm{c}} \pm 0.184$ & $1.13^{\mathrm{c}} \pm 0.172$ & $9.54^{\mathrm{a}}+0.189$ & $5.98^{\mathrm{b}}+0.153$ & 0.017 \\
\hline Protease & $10.22^{\bar{c}}+3.25$ & $13.57^{\bar{c}} \pm 5.75$ & $26.33^{\bar{b}}+5.65$ & $65.95^{\mathrm{a}}+4.89$ & $27.50^{\bar{b}}+5.63$ & 0.010 \\
\hline Cellulase & $3.45^{\mathrm{d}} \pm \overline{3} .11$ & $9.23^{\mathrm{c}} \pm \overline{1} .05$ & $16.33^{\mathrm{b}} \pm 1.99$ & $27.93^{\mathrm{a}} \pm 2.11$ & $18.42^{\mathrm{b}} \pm 2.45$ & 0.008 \\
\hline Xylanase & $6.73^{\mathrm{d}} \pm 2.56$ & $13.59^{\bar{c}} \pm 3.29$ & $24.76^{\mathrm{b}} \pm 1.85$ & $35.19^{\mathrm{a}} \pm 3.15$ & $26.59^{\mathrm{b}} \pm 2.56$ & 0.020 \\
\hline \multicolumn{7}{|c|}{ In small intestine content:- } \\
\hline Amylase & $35.84^{\mathrm{d}} \pm 5.17$ & $43.18^{c} \pm 8.25$ & $112.92^{\mathrm{b}} \pm 15.02$ & $162.86^{\mathrm{a}} \pm 6.12$ & $114.80^{\mathrm{b}} \pm 4.16$ & 0.012 \\
\hline Protease & $7.89^{c} \pm \overline{2} .45$ & $10.27^{\mathrm{b}} \pm 3.15$ & $16.25^{\mathrm{b}} \pm \overline{4} .23$ & $28.75^{\mathrm{a}} \pm \overline{2} .01$ & $18.25^{\mathrm{b}} \pm \overline{3} .76$ & 0.009 \\
\hline Cellulase & $24.27^{\mathrm{f}} \pm 3.99$ & $32.51^{\mathrm{d}} \pm 3.31$ & $119.27^{\bar{c}} \pm 9.75$ & $168.02^{\bar{b}} \pm 11.36$ & $227.11^{\bar{a}} \pm 13.25$ & 0.011 \\
\hline Xylanase & $24.04^{\mathrm{d}} \pm 7.35$ & $56.43^{\mathrm{c}} \pm 6.29$ & $105.26^{\mathrm{b}} \pm 6.10$ & $165.49^{\mathrm{a}} \pm 5.17$ & $116.85^{\mathrm{b}} \pm 5.12$ & 0.019 \\
\hline
\end{tabular}

Table (4): Effect of different levels of ZADO® on blood parameters of broiler.

\begin{tabular}{lllllll}
\hline Item & Control & $\mathrm{Z} 1$ & $\mathrm{Z} 2$ & $\mathrm{Z} 3$ & $\mathrm{Z} 4$ & Prob. \\
\hline Total Protein g/dl & $3.686^{\mathrm{c}} \pm 0.15$ & $4.824^{\mathrm{b}} \pm 0.11$ & $5.029^{\mathrm{ab}} \pm 0.07$ & $5.572^{\mathrm{a}} \pm 0.12$ & $5.386^{\mathrm{a}} \pm 0.09$ & 0.04 \\
Albumin g/dl & $1.266 \pm 0.08$ & $1.097 \pm 0.10$ & $1.057 \pm 0.19$ & $1.005 \pm 0.08$ & $1.021 \pm 0.15$ & 0.07 \\
Globulin g/dl & $2.420^{\mathrm{c}} \pm 0.18$ & $3.727^{\mathrm{b}} \pm 0.20$ & $3.972^{\mathrm{b}} \pm 0.16$ & $4.567^{\mathrm{a}} \pm 0.21$ & $4.365^{\mathrm{a}} \pm 0.19$ & 0.05 \\
A/G ratio & 0.523 & 0.294 & 0.266 & 0.220 & 0.234 & \\
Total lipids mg/dl & $454.27 \pm 22.5$ & $407.02 \pm 24.2$ & $507.02 \pm 29.4$ & $455.41 \pm 21.3$ & $384.06 \pm 26.2$ & 0.08 \\
cholesterol mg/dl & $117.085 \pm 23$ & $93.60 \pm 20$ & $92.43 \pm 22$ & $100.70 \pm 21$ & $112.43 \pm 24$ & 0.09 \\
AST IU/L & $30.20 \pm 3.12$ & $30.20 \pm 1.10$ & $25.00 \pm 2.29$ & $23.40 \pm 1.19$ & $24.20 \pm 2.74$ & 0.75 \\
ALT U/L & $44.20 \pm 2.98$ & $43.83 \pm 3.11$ & $43.34 \pm 2.22$ & $42.86 \pm 1.67$ & $43.18 \pm 2.67$ & 0.68 \\
Ca (mg/dl) & $9.86 \pm 0.16$ & $10.21 \pm 0.76$ & $10.19 \pm 0.27$ & $10.15 \pm 0.33$ & $10.09+0.18$ & 0.68 \\
P (mg/dl) & $5.86 \pm 0.51$ & $6.23 \pm 0.17$ & $6.19 \pm 0.15$ & $6.05 \pm 0.15$ & $6.17 \pm 0.24$ & 0.73 \\
creatinine (mg/dl) & $0.793 \pm 0.05$ & $0.789 \pm 0.03$ & $0.783 \pm 0.04$ & $0.723 \pm 0.05$ & $0.746 \pm 0.02$ & 0.59 \\
T3 ng/ml & $1.70{ }^{\mathrm{d}} \pm 0.16$ & $2.18^{\mathrm{c}} \pm 0.07$ & $2.46^{\mathrm{b}} \pm 0.09$ & $2.94^{\mathrm{a}} \pm 0.04$ & $2.533^{\mathrm{b}} \pm 0.08$ & 0.04 \\
$\mathrm{~T} 4 \mathrm{ng} / \mathrm{ml}$ & $13.73 \pm 0.28$ & $13.37 \pm 0.48$ & $13.11 \pm 0.46$ & $13.43 \pm 0.21$ & $14.12 \pm 0.36$ & 0.07 \\
\hline
\end{tabular}

$\overline{a, b c}$ Means within the same row with different letters are significantly differ.

The values of plasma constituents in broilers at 35 days of age (Table 4) were within the normal ranges for plasma total cholesterol, total protein and albumin.

Regarding to liver function expressed as plasma AST and ALT enzymes, data recorded in Table (4) clearly indicate non-significant variations between control and other treatments. The histological sections on liver confirmed these findings. The same trend was recorded for creatinine levels, as an indicator for kidney function, where no effects of $Z A D O \circledR$ were recorded. Plasma liver enzymes activities values (AST and ALT) at $42 \mathrm{~d}$ of age of broilers (Cobb strain) in the current trial are within the normal range (Viveros et al., 2002). Enzyme supplementation of chicken diets is employed in order to increase the availability of starch, protein and other macronutrients that are entrapped by intact cell wall structures or viscous polymers that are resistant to digestion by endogenous host enzymes (Frigard et al., 1994). The current trial indicated also, that broiler diets supplemented with ZADO® increased significantly the protein and globulin levels in plasma, which might supported by the enhancement of immune organs (spleen and bursa). It is well stated that gama-globulin is the main component of anti-body production, which presents the humoral immune response. So, findings of globulin levels in plasma in the current study are supported by Gao et al. (2007), who suggested that xylanase supplementation, to wheat-based diets for cockerels from 7 to $21 \mathrm{~d}$ of age enhanced the humoral immune response.

Concerning calcium and phosphorus levels, it was noticed that there were no significant differences among all groups. On the other hand, concerning thyroid hormones, our results in Table (4) indicate that plasma thyroid hormones concentrations were seems to be significantly differed among treatments. The highest values were recorded for chicken given ZADO® $0.5 \mathrm{Kg} /$ ton. No effect of treatment on T4. T3 levels raised in treated groups and free T4 levels declined compared with control group. These findings 
may reflect a good feed utilization, absorption and metabolism for birds when diets supplemented with ZADO®.

The current experiment showed a favour effect of enzyme addition to broiler diets up to $35 \mathrm{~d}$ of age on reducing the cholesterol level in plasma, suggesting that enzyme supplementation might play a role in broiler lipid metabolism. Unfortunately, little information has been published on the effects of enzyme supplementation in broiler diets on blood lipid metabolites. However, Onilude and Oso (1999b) reported that the supplementation of enzyme mixture including amylase, cellulase and pectinase to broiler fibercontaining diets from hatch to $42 \mathrm{~d}$ of age reduced blood lipid metabolites including plasma cholesterol level from 246 to $136 \mathrm{mg} / \mathrm{dL}$ at $42 \mathrm{~d}$ of age. Also, Cowieson et al. (2013) reported that phytase addition to broiler diets reduced total cholesterol concentration in the blood of chickens fed the positive control diet (adequate in $\mathrm{P}$ and $\mathrm{Ca}$ ) but, increased cholesterol concentrations in the blood of chickens fed the negative control diet (with $\mathrm{P}$ and Ca levels reduced by 0.12 and $0.14 \%$, respectively) however, no effects of phytase on total- and HDL-cholesterol were noted. They hypothesized that enzyme addition with adequate minerals levels ( $\mathrm{Ca}$ and $\mathrm{P}$ ) might reduce the cholesterol content in the plasma, which might explain, at least in part, the reduction of cholesterol level in plasma in response to dietary ZADO® by providing improvement of feed digestion and enhancement of mineral absorption. In contrast, Saricaet al. (2005) reported that xylanase supplementation in broiler diets based on wheat-corn-SBM did not affect cholesterol content in plasma (169.4 vs. $180.6 \mathrm{mg} / \mathrm{dL}$ for treated and control groups, respectively). Frigard et al. (1994) noted a higher serum cholesterol level in broilers at $21 \mathrm{~d}$ of age fed rye-corn-SBM based diet supplemented with commercial enzyme ( $2 \mathrm{~g} / \mathrm{kg}$ diet; GP- 5000, based on beta-glucanases and xylanases) than those of birds fed the corresponding un-supplemented diet and attributed that to the elimination of the dietary fibre effect on reducing cholesterol content in the serum by the enzyme supplementation. In conclusion, the response of broiler blood metabolites to enzyme supplementation is based not only on ingredient 'quality' but also on bird age, environmental conditions, managerial conditions, enzymes preparations, duration of enzyme supplementations and the dose of supplementation.

\section{Carcass traits:}

The main results of carcass traits are set out in Table (5). Carcass, breast and thigh weights (as a percentage of carcass) were significantly greater $(\mathrm{P} \leq 0.01)$ in birds fed supplement of $\mathrm{ZADO}{ }^{\circ}$ than the control group.No effect of treatment on \% gizzard, liver, heart, spleen, bursa, abdominal fat and dram.

Table (5): Effect of different levels of ZADO® on carcass traits.

\begin{tabular}{|c|c|c|c|c|c|c|}
\hline Item & control & Z 1 & $\mathrm{Z} 2$ & $\mathrm{Z3}$ & $\mathrm{Z4}$ & Prob. \\
\hline carcass $\%$ & $61.13^{b} \pm 1.81$ & $65.92^{\mathrm{ab}} \pm 1.71$ & $68.66^{\mathrm{a}} \pm 3.21$ & $69.84^{\mathrm{a}} \pm 4.32$ & $69.46^{\mathrm{a}} \pm 1.45$ & 0.009 \\
\hline gizzard $\%$ & $2.02 \pm 0.33$ & $2.49 \pm 0.51$ & $2.24 \pm 0.26$ & $2.49 \pm 0.42$ & $1.91 \pm 0.35$ & 0.076 \\
\hline liver\% & $2.68 \pm 0.44$ & $3.22 \pm 0.25$ & $2.75 \pm 0.34$ & $2.69 \pm 0.31$ & $2.68 \pm 0.28$ & 0.081 \\
\hline heart $\%$ & $0.42 \pm 0.04$ & $0.48 \pm 0.05$ & $0.51 \pm 0.04$ & $0.54 \pm 0.05$ & $0.42 \pm 0.03$ & 0.059 \\
\hline spleen $\%$ & $0.13 \pm 0.03$ & $0.19 \pm 0.05$ & $0.51 \pm 0.02$ & $0.54 \pm 0.03$ & $0.42 \pm 0.04$ & 0.067 \\
\hline bursa\% & $0.12 \pm 0.06$ & $0.15 \pm 0.05$ & $0.19 \pm 0.06$ & $0.13 \pm 0.06$ & $0.12 \pm 0.03$ & 0.064 \\
\hline abdominal fat $\%$ & $1.49+0.59$ & $0.80 \pm 0.57$ & $0.74+0.85$ & $0.71 \pm 0.77$ & $1.15 \pm 0.63$ & 0.052 \\
\hline breast $\%$ & $22 . \overline{11}^{\mathrm{c}} \pm 0.19$ & $25.90^{\mathrm{b}} \pm 0.36$ & $25.1 \overline{9^{b}} \pm 0.41$ & $27.8 \overline{6}^{\mathrm{a}} \pm 0.19$ & $25.1 \overline{7}^{\mathrm{b}} \pm 0.39$ & 0.038 \\
\hline thigh\% & $4.43^{\mathrm{d}} \pm 0.16$ & $4.90^{\mathrm{c}} \pm \overline{0} .14$ & $5.41^{\mathrm{b}} \pm 0.19$ & $5.93^{\mathrm{a}} \pm 0.16$ & $5.41^{\mathrm{b}} \pm 0.11$ & 0.045 \\
\hline drum $\%$ & $4.916 \pm 0.92$ & $5.201 \pm 0.92$ & $5.16 \pm 1.00$ & $5.84 \pm 0.94$ & $5.19 \pm 0.85$ & 0.076 \\
\hline Intestine \% & $8.02 \pm 0.95$ & $7.86 \pm 0.89$ & $7.94+0.92$ & $7.12+0.99$ & $6.85+0.75$ & 0.064 \\
\hline
\end{tabular}

Dressing of broilers in the current trial represented by carcass relative weight was increased in response to dietary 6\% ZADO ${ }^{\circledR}$. Onilude and Oso (1999a) reported that the supplementation of three enzyme mixture (amylase, cellulase and pectinase) to broiler fiber-containing diets from 1 to $42 \mathrm{~d}$ of age increased carcass weight with a favor increase in its crude protein and ash content Moreover, Café et al. (2002) noted a significant increase in dressing percentage at $42 \mathrm{~d}$ of age in broilers given a corn-SBM diet supplemented with commercial enzymes. These also, are in agreement with Saleh et al. (2005) who reported that carcass relative weight was higher $(70.3 \mathrm{~g} / 100 \mathrm{BW})$ for broilers fed pure carbohydrases (cellulase, hemicellulose and pectinase) than control group $(68.6 \mathrm{~g} / 100 \mathrm{BW})$ with broilers fed a commercial enzymes (Energex) intermediate $(70.0 \mathrm{~g} / 100 \mathrm{BW})$. They attributed the improvement of carcass yield to the effects on crude protein metabolize ability. An increase in carcass is a typical response to increased protein: ME ratio (Donaldson et al., 1958; Mabray and Waldroup, 1981; 


\section{El-Sanhoury and Ahmed}

Donaldson, 1985). This also, might be explained and supported by the improvement in BWG in this trial. In the current experiment, internal organs were not affected by the enzyme addition. These results are in agreement with Saleh et al. (2005), who stated no differences in liver relative weight in response to dietary mixed enzymes. Also, Gao et al. (2007) observed that xylanase supplementation in broiler diets based on wheat-corn-SBM did not affect gizzard relative weight. In addition, Saricaet al. (2005) reported that xylanase supplementation in broiler diets based on wheat-corn-SBM did not affect heart, liver or gizzard relative weights and Gracia et al. (2003) reported that alpha-amylase supplementation in broiler diets based on corn did not affect liver or gizzard relative weights. However, Iji et al. (2001) indicated that the maximum weights of these organs are reached before $9 \mathrm{~d}$ of life. Also, Barekatain et al. (2013) observed a negative interaction between xylanase and protease resulting in a reduction in relative weight of gizzard at $21 \mathrm{~d}$ of age but, these differences were not noted at $7 \mathrm{~d}$ of age. They attributed that to the high insoluble fiber content, which played a stimulating role in gizzard development.

The present study showed that $0.5 \mathrm{Kg}$ ZADO® supplementation to corn-based diets slightly increased (but not significantly) the relative weight of the spleen and bursa suggesting that enzyme supplement accelerated the development of the immune organ. To my knowledge few studies have been studied the effects of enzyme supplementation to corn-based diets on the immunity of poultry. However, Gao et al. (2007) observed that xylanase supplementation to wheat-based diets for cockerels from 7 to $21 \mathrm{~d}$ of age significantly increased the relative weight of the spleen. They attributed that to the improvement of feed digestion, the enhancement of nutrients absorption and the regulation of metabolic hormones in response to the addition of the enzyme, which in turn could have an effect on body immunity.

\section{Histological results:}

Histological examinations of the intestinal sections are illustrated in Figure (1). It is clear from the transverse sections (T.S) that the villi height increased in treated groups compared with the control one.

The observations from the histological sections for small intestine in broiler group fed with ZADO® $0.5 \%$ showed developmental increasein intestinal villi length and number more than other groups fed with ZADO® 0.3 and $0.7 \mathrm{Kg}$ when compared with sections taken from ZADO® 0.1 group and control group fed with basal diet.

The observations from the liver histological sections in broiler group fed with ZADO® concentrations showed normal distribution for cells and ducts, absence of any lesions when compared with control group fed with basal diet without ZADO® supplementation.

Table (6): Effect of different levels of ZADO® on Economic Efficiency.

\begin{tabular}{llllll}
\hline Parameters & Control & Z1 & Z2 & Z3 & Z4 \\
\hline Price Kg feed(LE) & 2.29 & 2.31 & 2.35 & 2.39 & 2.43 \\
Total feed cost(LE) & 7.38 & 7.52 & 7.84 & 8.14 & 8.10 \\
Average Weight Gain(Kg/Chick) & 1.575 & 1.685 & 1.785 & 1.895 & 1.805 \\
Total Return (LE) & 18.9 & 20.22 & 21.42 & 22.74 & 21.66 \\
Net Return (LE) & 11.52 & 12.70 & 13.58 & 14.60 & 13.56 \\
Economic Efficiency (\%) & 155.97 & 168.97 & 173.37 & 179.49 & 167.31 \\
PI & 80.25 & 90.75 & 99.17 & 109.23 & 101.37 \\
PEF & 217.82 & 248.91 & 274.85 & 305.86 & 280.93 \\
livability \% & 95 & 96 & 97 & 98 & 97 \\
\hline
\end{tabular}

The highest values of Economic Efficiency, performance index (PI) and Production Efficiency Factor (PEF) were recorded for chicken given $\mathrm{ZADO}{ }^{\circledR} 0.5 \mathrm{Kg} /$ ton.

However, this increase was more obvious in groups that were fed basal diets supplemented with ZADO® groups. Furthermore, there were great variations in the size and number of Crypts of Lieberkuhn associated with the supplemental additives. These Crypts are known to secrete fluids containing different vital substances essential for the internal micro-environment of the small intestine segments (Hodges, 1974). While the sections from the liver parenchyma of the control treatment Fig. (2) has normal hepatocytic structure with dilated central vein engorged with blood. Also, there were dark stained eosinophilic cells surrounding or near the central veins. There is moderate hypertrophy of liver cells especially in (Z4 group) which may reveal hyperactivity of the liver cells or a compensatory effect due to more degenerative (necrotic) areas in these sections. The above mentioned changes in liver sections may be related to the higher metabolic activity associated with the higher growth rates of broilers which depends on their genetic background. 
The histological observations in the present study may explain our results concerning the enhanced live body wight and immune responses of treated broiler groups.

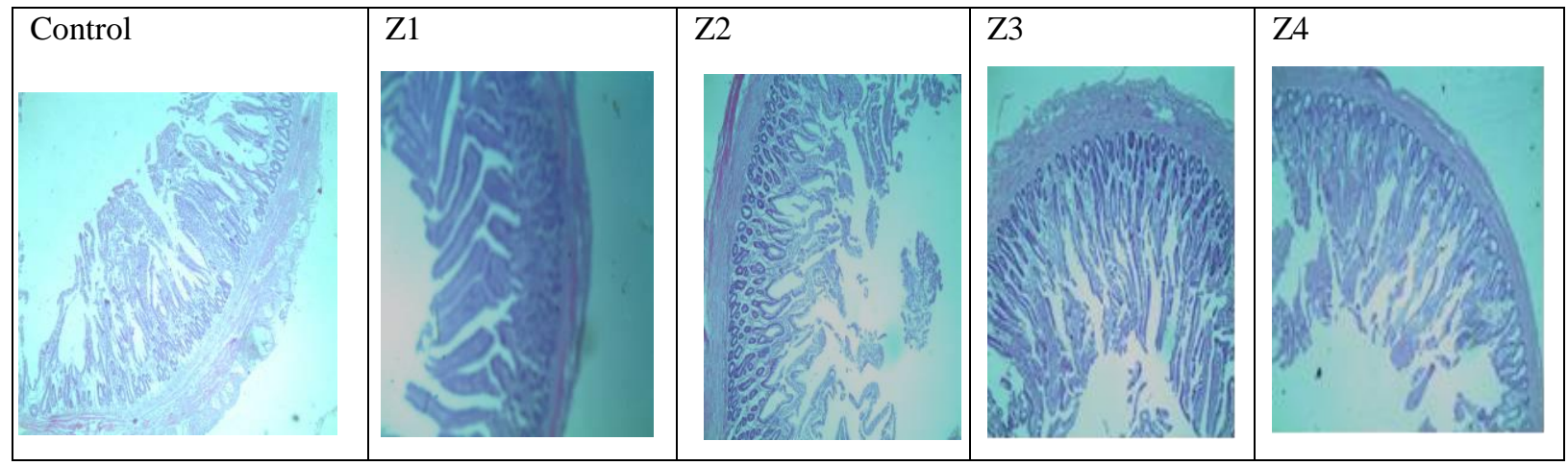

Fig. (1): The histological structure (at 40X) of the small intestine from broilers fed different biological additives and a control group.

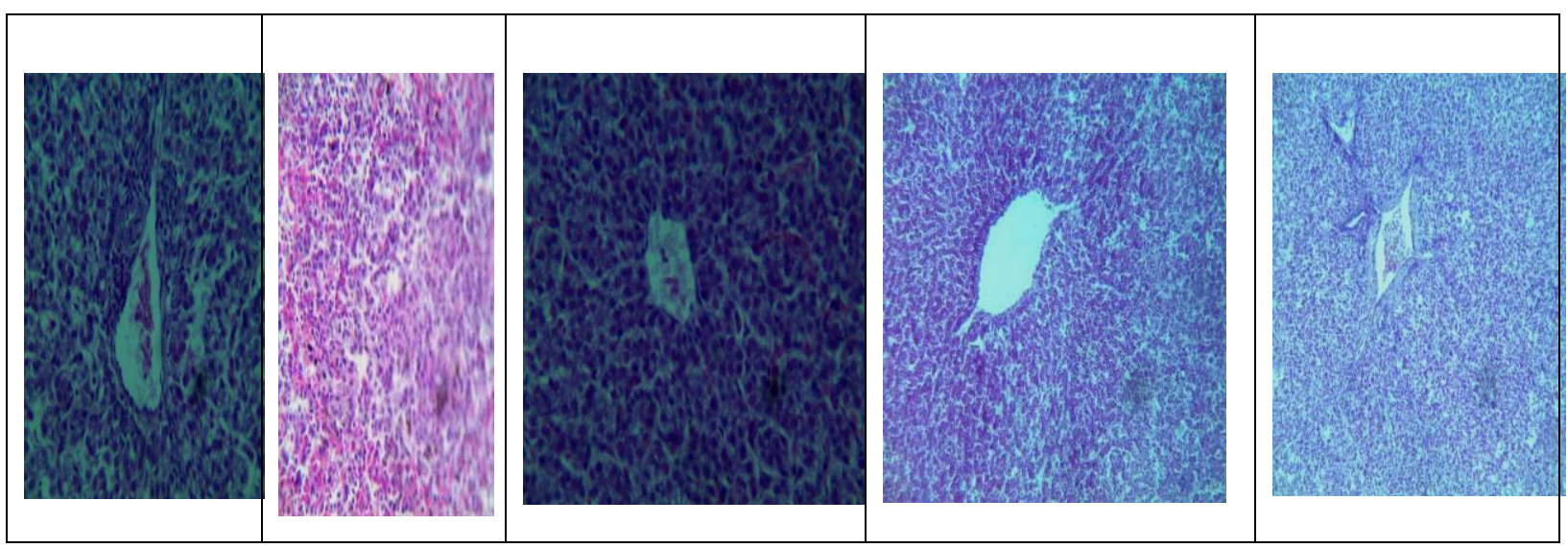

Fig. (2): The histological structure (at 40X) of the liver from broilers fed different biological additives and a control group.

\section{CONCLUSIONS}

It could be concluded that broiler diets supplement with $0.5 \mathrm{Kg}$ of ZADO ${ }^{\circledR}$ improved broiler productivity from hatch to 35 days of age. In addition, ZADO® supplementation might improve broiler immunity by accelerating the improvement of immune organs and increasing the total protein and globulin levels in plasma. Also, dietary $0.5 \mathrm{Kg}$ ZADO ${ }^{\circledR}$ has a favor effect on enzymes activity by the increase in stomach and intestine enzymes in ZADO® groups are good explanations for the improvements in the FCR. The histological and blood pictures showed that ZADO® products are very safe on birds and accordingly birds are safe for human consumption. In this respect, more studied are required to explain the mode of action of the effect of enzyme supplementation on immunity and blood constituents in broilers. Good of Economic Efficiency for ZADO® $0.5 \mathrm{Kg} /$ ton. Therefore, it could be recommended from this study to supplement $0.5 \mathrm{Kg}$ of $\mathrm{ZADO}{ }^{\circledR}$ to broiler diets from hatch to 35 days of age.

\section{ACKNOWLEDGEMENTS}

The author is grateful to Dr. Hany Gado, Animal Production Dept., Ain Shams University, Egypt, for providing the $\mathrm{ZADO}{ }^{\circledR}$ for free and to all the farm workers for their care and management of the broilers during the experiment. 


\section{El-Sanhoury and Ahmed}

\section{REFERENCES}

Angel, C.R., W. Saylor, S.L. Vieira and N. Ward (2011). Effects of a mono-component protease on performance and protein utilization in 7- to 22-day-old broiler chickens. Poultry Science, 90: 2281-2286.

AOAC (2000). In: Horwitz, W. (Ed.), Official Method of Analysis of the Association of Official Analytical Chemists International. vol. 1, 17th ed. AOAC International, Gaithersburg, MD, USA.

Barekatain, M.R., C. Antipatis, M. Choct and P.A. Iji (2013). Interaction between protease and xylanase in broiler chicken diets containing sorghum distillers' dried grains with solubles. Anim. Feed Sci. Technol., 182: 71-81.

Bedford, M.R.(2002). The role of carbohydrases in feedstuff digestion. Pages 319-336 in Poultry Feedstuffs: Supply, Composition and Nutritive Value. J. MacNab and N. Boorman, ed. CAB International, Wallingford, UK.

Café, M.B., C.A. Borges, C.A. Fritts and P.W. Waldroup (2002). Avizyme improves performance of broilers fed cornsoybean meal-based diets. J. Appl. Poult. Res., 11: 29-33.

Cowieson, A.J. and V. Ravindran (2008). Effect of exogenous enzymes in maize-based diets varying in nutrient density for young broilers: growth performance and digestibility of energy, minerals and amino acids. Br. Poult. Sci., 49: 37-44.

Cowieson, A.J., D.N. Singh and O. Adeola (2006). Prediction of ingredient quality and the effect of a combination of xylanase, amylase, protease and phytase in the diets of broiler chicks. 1. Growth performance and digestible nutrient intake. Br. Poult. Sci., 47: 477-489.

Cowieson, A.J., A. Ptak, P. Maækowiak, M. Sassek, E. Pruszynska-Oszmalek, K. Zyla, S. Swiatkiewicz, S. Kaczmarek and D. Jozefiak (2013). The effect of and blood biochemistry of broiler chickens fed wheat / cornbased diets. Poult. Sci., 92: 2124-2134.

Donaldson, W.E. (1985). Lipogenesis and body fat in chicks: effect of calorie-protein ratio and dietary fat. Poult. Sci., 64: 1195-1204.

Donaldson, W.E., G.F. Combs and G.L. Romoser (1958). Studies on energy levels in poultry rations. 1. Effect of calorie-protein ratio of the ration on growth, nutrient utilization and body composition of chicks. Poult. Sci., 35: 1100-1105.

Duncan, D.B. (1955). Multiple range and multiple F test. Biometrics 11: 1-42.

Emmert, J. (2000). Efficiency of phase-feeding in broilers. Proceeding, California Animal Nutrition Conference. May 10-11. Fresno California, USA.

Freitas, D.M., S.L. Vieira, C.R. Angel, A. Favero and A. Maiorka (2011). Performance and nutrient utilization of broilers fed diets supplemented with a novel mono-component protease. J. Appl. Poult. Res., 20: 322-334.

Frigard, T., D. Pettersson and P. Aman (1994). Fiber-degrading enzyme increases body weight andtotal serum cholesterol in broiler chickens fed a rye-based diet. J. Nutr., 124: 2422-2430.

Gado, H. (1997). Effect of enzymatic treatments for poorquality roughages on fiber digestibility and nitrogenmetabolism inBaladi goats. Egyptian J. Nutr.Feeds, pp: $50-56$ (special issue).

Gado, H.M. and A.Z.M. Salem (2008). Influence ofexogenous enzymes from anaerobic source ongrowth performance, digestibility, ruminalfermentation and blood metabolites in lambs fed oforange pulp silage in total mixed ration. In: $59^{\text {th }}$ Annual Meeting of the European Association forAnimal Production, Vilnius, Lithuania, August 24-27.p: 228. (Abstr.)

Gado, H.M., H.M. Metwally, H. Soliman, A.Z.L. Basiony and E.R. El-Galil (2007). Enzymatic treatments ofbagasse by different sources of cellulase enzymes. In: The 11th Conf. Animal Nutr., AlAqsor-Aswan, Egypt on November, 13-18, 10: 607.

Gado, H.M., A.Z.M. Salem, P.H. Robinson and M. Hassan (2009). Influence of exogenous enzymes onnutrient digestibility, extent of ruminal fermentationas well as milk production and composition in dairycows. Anim. Feed Sci. Technol., 154: 36-46. 
Gado, H.M., A.Z.M. Salem, N.E. Odongo and B.E.Borhami (2011). Influence of exogenous enzymesensiled with orange pulp on digestion and growthperformance in lambs. Anim. Feed Sci. Technol.,165: 131-136.

Gao, F., Y. Jiang, G.H. Zhou and Z.K. Han (2007). Theeffects of xylanase supplementation on growth, digestion, circulating hormone and metabolitelevels, immunity and gut microflora in cockerels fedon wheat-based diets. Br. Poult. Sci., 48: 480-488.

Gracia, M.I., M.J. Aranibar, R. Lázaro, P. Medel and G.G. Mateos (2003). Alpha-amylase supplementation of broiler diets based on corn.Poult. Sci., 82:436-442.

Halliwell, G. (1958). A micro determination of cellulase in studies with cellulase. Biochem. J., 68:605.

Hodges, R.D. (1974). The Histology of the Fowl. London, Academic Press, pp. 221-230.

Iji, P.A., A. Saki and D.R. Tivey (2001). Body and intestinalgrowth of broiler chicks on a commercial starterdiet. 1. Intestinal weight and mucosal development.Br. Poult. Sci., 42: 505-513.

Kalmendal, R. and R. Tauson (2012). Effects of axylanase and protease, individually or incombination and an ionophore coccidiostat onperformance, nutrient utilization and intestinalmorphology in broiler chickens fed a wheat-soybeanmeal-based diet. Poult. Sci., 91: 1387-1393.

Kocher, A., M. Choct, M.D. Porter and J. Broz (2002). Effects of feed enzymes on nutritive value ofsoybean meal fed to broilers. Br. Poult. Sci., 43:54-63.

Kocher, A., M. Choct, G. Ross, J. Broz and T.K. Chung (2003). Effects of enzyme combinations on AME ofcorn-SBM based diet in broilers. J. Appl. Poult. Res.,12: 275-283.

Lázaro, R., M. García, M.J. Araníbar and G.G. Mateos (2003). Effect of enzyme addition to wheat-, barley-and rye-based diets on nutrient digestibility andperformance of laying hens. Br. Poult. Sci., 44:256-265.

Mabray, C.J. and P.W. Waldroup (1981). The influence ofdietary energy and amino acid levels on abdominalfat pad development in the broiler chick. Poult.Sci., 60: 151-159.

Malik, C.P. and M.B. Singh (1982). Plant enzymology and histo-enzymology .Kalyani publishers, New Delhi - Ludhiana, Chapter 6:166.

Mandels, C. and J. Waber (1969). Effect of Carboxy Methyl Cellulase on source of fiber.Biochem. J., 79: 935.

Marsman, G.J.P., H. Gruppen, A.F.B. Van DerPoel,R.P. Kwakkel, M.W.A. Verstegen and A.G.J. Voragen (1997). The effect of thermal processing and enzymetreatments of soybean meal on growthperformance, ileal nutrient metabolisabilities andchyme characteristics in broiler chicks.Poult.Sci., 76: 864-872.

Mathlouthi, N., S. Mallet, L. Saulnier, B. Quemener and M. Larbier (2002). Effect of xylanase and alphaglucanase addition on performance, nutrientdigestibility and physico-chemical conditions in thesmall intestine contents and caecal microflora ofbroiler chickens fed a wheat and barley-baseddiet. Anim. Res., 51: 395-406.

Meng, X., B.A. Slominski, L.D. Campbell, W. Guenter and O. Jones (2006). The use of enzyme technology forimproved energy utilization from full-fat oilseeds.part I: Canola seed. Poult. Sci., 85: 1025-1030.

National Research Council (1994). Nutrient Requirements of Poultry.9th rev. ed. Natl. Acad. Press, Washington, DC, USA.

North, M.O. (1981). Commercial chicken. Production Annual. $2^{\text {nd }}$ edition, Av., publishing company I.N.C., West-post. Connecticut, USA.

Olukosi, O.A., A.J. Cowieson and O. Adeola (2007). Age-related influence of a cocktail of xylanase, amylase and protease or phytase individually or in combination in broilers. Poult. Sci., 86: 77-86.

Onilude, A.A. and B.A. Oso (1999a). Effect of fungal enzyme mixture supplementation of various fibrecontaining diets fed to broiler chicks 1: Performance and carcass characteristics. World J. Microbiol. Biotechnol., 15: 309-314. 


\section{El-Sanhoury and Ahmed}

Onilude, A.A. and B.A. Oso (1999b). Effect of fungal enzyme mixture supplementation of various fibrecontaining diets fed to broiler chicks 2: On blood, liver and kidney total lipids, triacylglycerols and cholesterol. World J. Microbiol.Biotechnol., 15: 315-320.

Osman, A.M. (1982). Amylase in chicken intestine and pancreas. Comp. Biochem. Physiol. 73B, 571.

Remus, J., M. Hruby and E.E.M. Pierson (2005). Impact of the Avizyme 1500 series on apparent ileal amino acid digestibility in poultry. Poult. Sci., 84(Suppl. 1): 11. (Abstr.)

Safaa, H.M., S.A. Riad, F.R. Mohamed, S.S. Siam and H.A. El-Minshawy (2010). Probiotic, prebiotic and yeast supplementation in broiler diets from 1 to 42 days of age: 2. Immune response and slaughter traits. Poult. Sci., 89 (Suppl. 1): 546-547. (Abstr.)

Saleh, F., M. Tahir, A. Ohtsuka and K. Hayashi (2005). A mixture of pure cellulase, hemicellulase and pectinase improves broiler performance. Br. Poult. Sci., 46: 602-606.

Sarica S., A. Ciftci, E. Demir, K. Kilinc and Y. Yildirim (2005). Use of an antibiotic growth promoter and two herbal natural feed additives with and without exogenous enzymes in wheat based broiler diets. S. Afr. J. Anim. Sci., 35: 61-72.

SAS Institute, 2004. SAS/STATs User's Guide.Version 9.1, SAS Institute Inc., Cary, NC, USA.

Viveros, A., A. Brenes, I. Arija and C. Centeno (2002). Effects of microbial phytase supplementation on mineral utilization and serum enzyme activities in broiler chicks fed different levels of phosphorus. Poult. Sci., 81: 1172-1183.

Walk, C.L., A.J. Cowieson, J.C. Remus, C.L. Novak and A.P. McElroy (2011). Effects of dietary enzymes on performance and intestinal goblet cell number of broilers exposed to a live coccidian oocyst vaccine. Poult. Sci., 90: 91-98.

Zanella, I., N.K. Sakomura, F.G. Silversides, A. Fiqueirdo and M. Pack (1999). Effect of enzyme supplementation of broiler diets based on maize and soybeans. Poult. Sci., 78: 561-568.

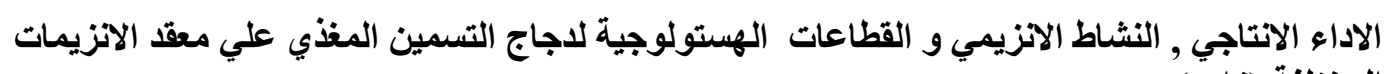

المختلفة (زادو)

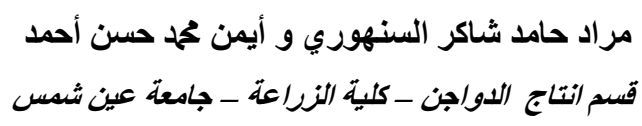

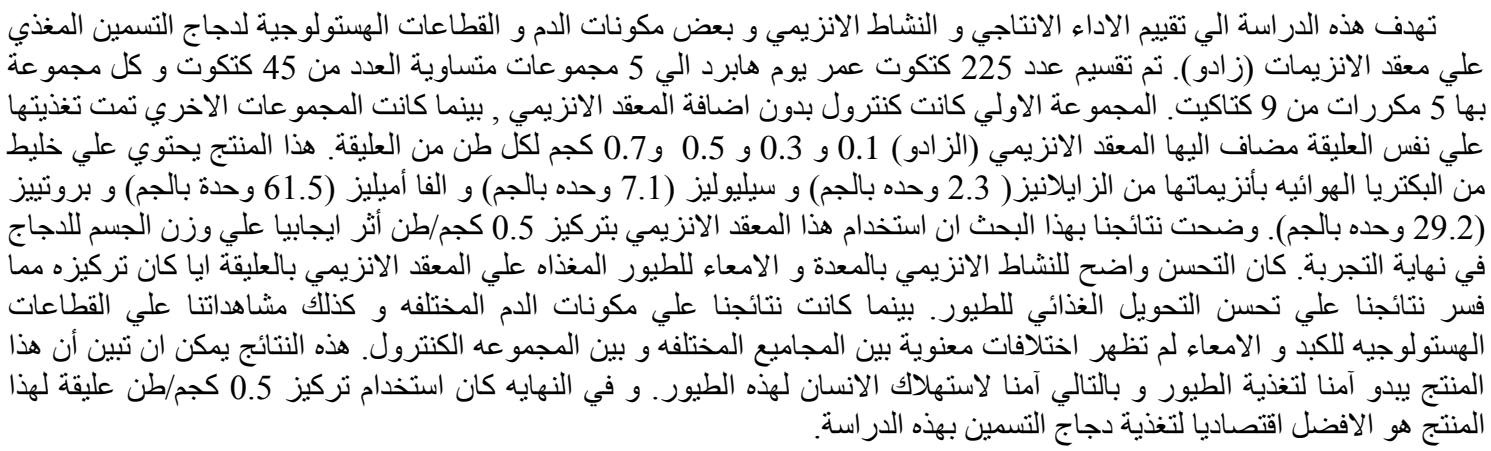

